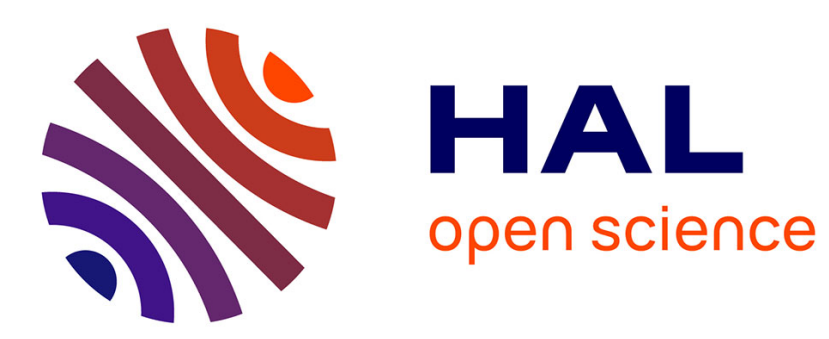

\title{
Whither Euroscepticism? The Uses of European Integration by Polish Conservative and Radical Parties
}

Dorota Dakowska

\section{To cite this version:}

Dorota Dakowska. Whither Euroscepticism? The Uses of European Integration by Polish Conservative and Radical Parties. Perspectives on European Politics and Society, 2010, 11 (3), pp.254-272. 10.1080/15705854.2010.503032 . halshs-01184147

\section{HAL Id: halshs-01184147 https://shs.hal.science/halshs-01184147}

Submitted on 13 Aug 2015

HAL is a multi-disciplinary open access archive for the deposit and dissemination of scientific research documents, whether they are published or not. The documents may come from teaching and research institutions in France or abroad, or from public or private research centers.
L'archive ouverte pluridisciplinaire HAL, est destinée au dépôt et à la diffusion de documents scientifiques de niveau recherche, publiés ou non, émanant des établissements d'enseignement et de recherche français ou étrangers, des laboratoires publics ou privés. 
Dorota Dakowska, «Whither Euroscepticism? The Uses of European Integration by Polish Conservative and Radical Parties », Perspectives on European Politics and Society, September 2010, vol. 11, n³, p. 254-272.

Dorota Dakowska

\section{Whither Euroscepticism? The Uses of European Integration by Polish Conservative and Radical parties ${ }^{1}$}

The impact of European integration on party politics has elicited a growing research interest. A sociological approach, focused on power relations and the redistribution of political resources by actors referring to 'Europe' has recently opened new research perspectives. This article considers to what extent the use of the reference to European integration has enabled conservative and radical Polish political parties on the right - such as the Law and Justice (PiS) and the League of Polish Families (LPR) - to modulate their position in relationship with other parties. The uses of European references will be analysed both in the transnational and the domestic political field, in order to discuss whether - and under what conditions - the critical reference to European integration may appear as a resource that enables the strengthening of the radical party leaders' discourse and visibility on the eve and in the aftermath of accession. The article argues that taking into account the domestic context, the relations between the political parties and the temporal dimension are necessary preconditions of a valid demonstration.

Keywords: Poland, Euroscepticism, Europeanization, Political parties, Conservatism, Extreme Right

While Europeanization $^{2}$ has become one of the most successful catchwords of European political studies, the impact of European integration on party politics at the national and supranational level has until a few years ago remained a more limited research area (Ladrech, 2002; Batory, 2002). A large number of studies have dealt with the phenomenon of 'Euroscepticism'3 in political parties, suggesting different explanations (Taggart, 1998; Kopecky and Mudde, 2002; Szczerbiak and Taggart, 2002, 2003, 2004, 2008; Harmsen and Spiering, 2004). However, few of them have analysed how the European factor structures the 
political competition while transcending the national and supranational political fields (Roger, 2001, Neumayer 2006, 2008; Harmsen, 2008). This dynamic approach of the social uses of European integration, focused on the redistribution of political resources by actors referring to 'Europe' and opposed on this issue has opened new avenues of research (Goetz and Hix, 2000; Jacquot and Woll, 2004; Baisnée and Pasquier, 2007).

The aim of my paper is to discuss the extent to which the use of the reference to European issues has enabled right-wing radical and sovereignist parties in Poland to modulate their positions in the domestic political field. This 'Europeanization' of party competition at the national level will be analysed with the case of two parties, which have referred in a critical way to the European integration process: the Law and Justice (Prawo $i$ Sprawiedliwość, PiS) and the League of Polish Families (Liga Polskich Rodzin, LPR) (see table 1). These two parties have not emerged in a political vacuum; they stem from other parties and movements, which should also be taken into account. They compete with parties labelled as liberal, agrarian or left-wing movements, who also shape the political debate and redraw the lines of political division.

In the first part, I will discuss the Europeanization of political competition from a theoretical and empirical point of view. In order to place the analysis in a broader temporal context and to stress the significance of transnational factors, I will shed light on the affiliation process of political parties from the candidate states to European party federations, which took place the second half of the 1990s. At the time, the full support to the European integration process with commitments to the federalist model appeared to be a criterion of selection of Central and Eastern European (CEE) parties and a factor of differentiation between them (Dakowska, 2005). Critical views of European integration and nationalist arguments were then likely to become factors of marginalisation, stigmatisation or exclusion either of political parties or of some of their leaders. Some authors claim that transnational party organisations exerted conformist pressures on the political parties from Central and Eastern Europe, producing 'formal but also real changes in party positions and behaviour, including by Eurosceptical parties' (Pridham, 2008: 100). The Polish case study provides an opportunity to test this hypothesis. Taking into account the pre-accession years is important to understand the relative 'Europeanization' of the competition between political parties in the candidate states, as it was both a period of intensive socialisation of party elites to European politics and of progressive radicalization of some parties' positions on European integration.

Secondly, the uses of European issues will be analysed in the domestic political field, in order to discuss whether - and under which political conditions - the critical reference to 
European integration may be used as a resource that enables the strengthening of the party's position, visibility or electoral results. However, focusing on Eurosceptical positions may also entail risks for some parties (Evans, 1998). The way the EU is invoked on the eve and in the aftermath of accession and the other issues with which it is associated will be taken into account. Focusing on the use of European issues in the party discourse is an interesting case for the analysis of political temporalities of the party competition. The party positions on European integration and its specific aspects are not stable elements of party cleavages - they can evolve (Neumayer, 2006, 2008; Szczerbiak, 2008) along with the restructuring of the more general 'national European discourse' (Harmsen, 2008). The position as a government or opposition party and the competition for a similar electorate may modify the parties' discursive repertoires. The relational analysis of party political positioning presents several advantages. First, it allows us to tackle the issue of the dynamics linked to the contextual party status as a government or opposition member. The position of the conservative PiS has altered as the party changed its status from government party to leading opposition party. The League of Polish Families' position on European issues, although it remained critical, underwent several changes and has been characterised by ambiguities. Taking into account the latter party, usually classified as 'hard Eurosceptic' provides a challenge to the hypotheses, which consider the radical rejection of the EU as hardly compatible with government participation (Henderson, 2008). Secondly, the time factor should be better taken into account, focusing both on the pre-accession and the post-accession period. Critical moments such as the accession referendum or the debate on the EU constitutional treaty provide useful case studies to observe these dynamics.

\section{The progressive Europeanization of political competition at the domestic level}

In the last few years, numerous studies have dealt with the phenomenon of Europeanization of the national political space (Radaelli, 2000, 2001; Green Cowles, 2001; Héritier \& al, 2001; Featherstone and Radaelli, 2003). The Europeanization framework has also been applied to the former candidate states - and now to new EU members (Schimmelfennig and Sedelmeier 2005). The impact of EU enlargement on polities and policies of the candidate countries - and new member states - has been extensively analysed. Also the question of the Europeanization of the political dimensions (party system, political parties, political discourse and controversies) is no longer a terra incognita in the growing and still dynamic field of EU 
studies (Lewis and Mansfeldová, 2006; Batory, 2009; Haughton, 2009; Whitefield, Rohrschneider, 2009). However, the interpretations of this party political dimension differ widely. While studies focused on a macro level provide useful data on the relationship between the parties positioned along traditional dividing lines and their proclaimed attitude towards European integration, they are usually characterised by the classification bias. A more qualitative analysis of the uses of European reference in the competition between parties at the national level enables us to grasp the dynamics and political conditions of these practices (Haughton, Rybáŕ, 2009). Taking into account the progressive development of transnational links with the European party families is useful to understand both the incremental and reversible nature of this identification process.

\section{Explaining the salience of European issues in the national political sphere}

The impact of European integration on the party systems, strategies and programs has benefited from increasing academic attention in the last few years. Several authors like Peter Mair have observed the limited impact of European integration on national party systems according to Sartori's classical criteria: their format and their mechanisms (Mair 2000). Concerning the CEE party systems, a similar diagnosis has been made of an overall limited EU impact on party organization and programmes, although the EU has acted as a constraint ('conductor') or a point of reference ('fellow passenger') (Haughton, 2009). Some authors have suggested that the EU had a more important impact on the CEE parties' structuring, as 'attitudes to the EU have become a factor in coalition formation' (Henderson, 2008: 114). For others, while the EU impact on party stances seems to have remained limited, the salience of the European issues has increased in the period preceding and following the accession (Whitefield, Rohrschneider, 2009).

The academic debates on party positions on European integration have discussed ideological vs. strategic factors, but also the weight of domestic policies (Hellström, 2008; Szczerbiak, Bil, 2009). Although some authors have stressed the importance of short- and long-term party strategies (Batory, Sitter, 2004), most of them seem to focus on the ideological issues. A number of studies dealing with different political parties across Europe focus on the relationship between party attitudes towards European integration and the traditional ideological divisions on the left/right axis. Authors attached to the explanatory value of the cleavage theory consider that a stabilised party ideology is the main variable determining party attitudes towards European integration: thus, European integration being a 
new issue on the political agenda, 'parties strive to encapsulate it within their established ideologies' (Marks, Wilson, Ray, 2002: 585). Another theoretical approach discusses whether the 'European cleavage' should be considered as an independent issue, which restructures party conflicts or whether the EU issues tend to be absorbed by more traditional cleavages (Fuchs, Roger, Magni-Berton, 2009 b). It suggests that the answer depends on the definition of cleavage: the restrictive definition leads to the conclusion that European issues are absorbed. According to the extensive definition, the EU has the power to modify political conflicts and to replace old fault lines with new ones (ibid.). While admitting that European integration did not create new cleavages, nor restructure party systems in a significant way, Robert Harmsen recognises the growing place that European issues take in the national debates. Consequently he suggests taking a careful look at the way in which these European issues are integrated in the national party competition by parties competing for government positions as well as by protest parties (Harmsen 2005).

Authors working with an impressive amount of data gathered in the Eastern and the Western parts of Europe tend to confirm statistically that party attitudes towards European integration may be placed in a bipolar space (Marks, Wilson, Ray, 2002; Hellström, 2008; Marks, Hooghe \& al., 2006; Marks, Hooghe \& al., 2007). Opposition to integration can thus be found on the extreme left and right, while mainstream parties support European integration, the EU being a centrist project: 'The European Union has been created by mainstream parties - Christian democrats, liberals, social democrats, and conservatives which have dominated national governments, national parliaments, the European Parliament, and the European Commission. Many noncentrist parties attack European integration as an extension of their domestic opposition' (Marks, Hooghe \& al. 2006: 163).

Although these authors have admitted possible errors related to the collected data mainly electoral manifestos, expert data, and MPs surveys, the method used could be further questioned as it privileges quantitative correlations and closed questions. The second limit is that both the survey and the analysis reproduce a classificatory approach. The result situates each party on a single axis reduced to the left/right divide, ${ }^{4}$ according to its degree of support for European integration. This approach presents the party positioning on European issues as stable but does not tell much about the varying uses of the European reference in the competition between parties.

When the political parties of the post-communist area are considered, two biases have already been pointed out by scholars working on this topic (De Waele, 2003). In the first 'cultural' bias, the political parties and cleavages of the region are considered as 
fundamentally different from those in other areas because of their particular history, mobilisations and culture. In the second bias, it is presumed that the CEE political arenas, party positioning and electoral behaviour are identical to those found in countries that founded the European Community. However, recent comparative studies have managed to avoid those biases, showing the general convergence of patterns of Euroscepticism in Western and Eastern Europe while stressing the specificities of the CEE party politics (Henderson, 2008).

Scholars working on the party politics of Euroscepticism have tended to compare the patterns of critical positioning towards European integration in both parts of Europe (Taggart and Szczerbiak 2002, 2004; Marks, Hooghe \& al., 2006). They show differences in the positioning of left and right parties in CEE countries and Western Europe on European issues However, with large cross-country comparisons the similarities are striking. Still, these studies feed the debate, as they continue to use labels such as 'hard' and 'soft' Euroscepticism (Taggart and Szczerbiak, 2002, 2004), which entail several difficulties in the categorization of parties and their discourse (Kopecký and Mudde, 2002; Neumayer, 2008). The debate aiming to restrict the definition of Euroscepticism has shown its limits ("how many extensions of sovereignty must a party oppose before it can be categorised as Eurosceptic?' (Taggart and Szczerbiak, 2003: 13). In his recent work Szczerbiak (2008) admits that it is difficult to apply the comparative framework of hard and soft Euroscepticism to CEE political parties as it is often impossible to find statements on their positioning regarding EU integration. In the preaccession period, most of the party leaders' judgements on European issues focused on the conduct of the accession negotiations. It was more difficult to find statements on the 'substance of the European integration project', let alone about 'the current and future EU trajectories'.

Understanding the logics of party positioning in a particular political context or region seems a prerequisite to avoid the conclusion of a 'natural affinity' between discourses or political preferences of a certain type and a particular kind of Euroscepticism (Taggart and Szczerbiak, 2003: 21). If we consider party attitudes towards European integration along the left/right divide, it is sometimes assumed as self-evident that parties on the left are in general more critical of EU integration than the parties on the right. This claim may be historically anchored and valid for the founding countries of the European Community (EC). But it is not necessarily convincing when we look on the one hand at the CEE parties issued from former communist organisations, who have in a large majority pronounced themselves strongly in favour of European integration. This commitment, as well as the democratic label attributed by the Socialist International in the 1990s, was a vital element of their legitimization (Devin, 
1998; Neumayer, 2003). On the other hand, in the CEE some of the most prominent moderately Eurocritical messages have been voiced by centre-right/right wing politicians. Beyond Václav Klaus in the Czech Republic, and the Polish right wing parties analysed in this paper, one could also mention the Slovak Christian Democratic Movement (KDH) (see also Henderson, 2008; Haughton, Rybáŕ, 2009).

An interesting perspective has been opened by scholars who have analysed the way in which the European variable structures party competition while transcending the national and European political fields. Laure Neumayer $(2006,2008)$ has showed the plasticity of CEE party positions on European integration. These positions may evolve alongside the other principles of division of the socio-political space. Also, Aleks Szczerbiak has explained that what was labelled as a 'Eurosceptic' positioning may very well rather be a result of 'shortterm tactical-strategic calculations' (Szczerbiak, 2008: 240) than the expression of a deeplyrooted ideology.

In this perspective, we can analyse the uses of the reference to European integration in the positioning of conservative and radical parties on the right in Poland. I will deal mostly with the example of Law and Justice and of the League of Polish Families, who emerged before the parliamentary elections of 2001. The former was composed of groupings originating from the large coalition of conservative and catholic parties Solidarity Election Action (AWS), which governed in the years 1997-2001. The latter gathered various minor nationalist and clerical movements to form a party in May 2001, on the eve of the 2001 elections. PiS and LPR formed a coalition government in the years 2006-2007, together with the Self-Defence (Samoobrona) peasant party. However, their positions in the national party competition differ. Law and Justice, which has positioned itself on the conservative right with a traditional and partly nationalist discourse, remains a party that could be labelled as a mainstream party, as it strives for participation in the national executive. The League of Polish Families, on the contrary, appears as a protest party drawing on the repertoire of the extreme right. While it tried to distinguish itself on the European issues, the League of Polish Families also mobilised traditional nationalist rhetoric based on National Democracy (ND) ideology from the interwar period, ${ }^{5}$ but also numerous historical references and strong antiGerman accents (Czernicka 2004). The LPR's participation in the 2006-2007 government, in which it was represented by two Ministers, led to internal and external tensions and can be considered as incidental. A relational analysis should help us include the logics of demarcation of these parties from other parties they were competing with. 


\section{The supranational affiliation as search for legitimacy in the pre-accession period}

The development of transnational links with the EP party groups was presented as a factor - among others - of the Europeanization of political parties (Ladrech, 2002). However, analysing these changing links is also a way to see to what extent the parties can take advantage of the European arena to pursue their own agendas (cf. Harmsen, 2005). The formal association of new members to party federations began in the second half of the 1990s, with the first signs of the stabilisation of CEE party landscapes and the consolidation of the reform process. Launching the formal enlargement process with the Copenhagen European Council and the first applications for membership provided serious incentives for EU national parties and their federations to switch from dialogue to cooperation with potential partners. ${ }^{6}$ Starting in 1998, associate member status was offered to political parties from CEE by the European party federations. The progressive association to European party structures with their congresses and their working groups offered useful socialisation forums (Dakowska, 2005).

According to Geoffrey Pridham (2008), transnational party cooperation launched mainly by EU-wide organisations involved three kinds of conditions: ideological compatibility, democratic conditionality and pro-EU commitment. There is no doubt that these criteria represented the basic logic of party political rapprochement. However, their practical application could be refined in several ways. First, the process of observation, rapprochement and selection of the most adequate partners may be analysed in its reciprocity. For CEE parties, affiliations were a source of information, programmatic references and legitimacy. European party federations may be considered as formal institutions providing the applicant party leaders with material and ideational resources that enable them to take advantage of opportunities for the evolution of their activity both at national and European level (Dakowska 2002, 2005). Secondly, ideological reasons were not the only criteria on which the launching of a closer cooperation depended. Strategic reasons - or the so-called logic of expected consequences (March, Olsen, 1998) - were also highly important. European political leaders were looking for future partners that would not only be ideologically compatible with them but also capable of strengthening the group after their accession. Also, some CEE parties sought to get associated to party federations, which carry weight in the European Parliament. ${ }^{7}$ Others opted for an affiliation, which seemed ideologically closest to their initial positioning before revising their initial choice according to their domestic evolution, as was 
the case with the Hungarian FIDESZ. These ideological and strategic reasons were combined in several ways (Dakowska, 2002). Thirdly, the choice of affiliation was also closely related to strategic repositioning at the national level. The changes of affiliation, which happened on the eve of the EU accession, may be grasped more clearly within this context.

This affiliation process, as well as the observation period preceding the accession, was an opportunity for mutual learning, socialising to European rules, but also for refining their own position. The choice of the Polish Freedom Union (Unia Wolności, UW) leaders to leave the EPP and cross over to the European Liberals was mostly linked to domestic patterns of inter-party competition. The Civic Platform (Platforma obywatelska, PO), which emerged as a major competitor of the UW after a partial split of the latter, was warmly welcomed as a partner by the EPP because of its positive electoral results of 2001. As the UW started its repositioning towards the centre-left, stressing its liberal commitment, the path towards a change of the initial transnational affiliation was open. As the decision of leaving the EPP was contested within the UW direction, the presidency of the European Liberal, Democrat and Reform Party (ELDR), initiated several efforts to convince the hesitating leaders and finalise the process (Dakowska, 2005).

After the split of the Solidarity Electoral Action (Akcja Wyborcza Solidarność, AWS) coalition and the creation of the PiS in 2001, its MPs opted for an affiliation with the Union for Europe of the Nations (UEN), which they joined during their period as observers in the European Parliament. This choice was later confirmed after the European elections of 2004 and $2009 .^{8}$ It was linked to the party's positioning on the conservative right in the national arena, with a discourse appealing to 'sovereignty', 'national interest' and 'patriotism'. As some of these politicians already had an experience of the dialogue with the European People's Party (EPP), due to their former contacts as AWS members, they claimed a general convergence between their priorities and those of other Polish MEPs situated on the right wing of the EPP. ${ }^{9}$ However, aiming to distinguish themselves from their counterparts from the Civic Platform, perceived as more pro-integrationist, they kept emphasising the benefits of being part of a smaller group and thus more able to influence it than their liberal opponents in the 'German-dominated' EPP. ${ }^{10}$

In some cases, a split in the transational affiliation in the European Parliament expressed an internal divide within a party. The Polish Peasant Party (Polskie Stronnictwo Ludowe, PSL) MEPs also illustrate this, as they were scattered between the EPP and the UEN during their first period in the EP (2004-2009). ${ }^{11}$ Transnational affiliations have been noticeably volatile both in the most pro-integration and in the most Eurosceptical parties. For the LPR 
representatives, the Polish accession referendum of June 2003 was an opportunity to announce a turning point in their relations with the European institutions. Before the referendum, some of them refused to go to Brussels and to work as observers. ${ }^{12}$ After the referendum, in which voters expressed a massive support to the accession, ${ }^{13}$ the discourse of the LPR changed. Its leaders announced their active participation in the European institutional process as the new way to defend the 'Polish interests'. This shift, which has been qualified by some analysts as a turn towards a more 'soft Euroscepticism' (Markowski 2006) was controversial within the LPR. Some of its leaders criticised Roman Giertych's declaration to the press in the aftermath of the accession referendum, in which he confessed, 'I am a European' to bolster this new image of political acceptability. ${ }^{14}$ The accession period was energetically used by the LPR to reinforce its visibility and its European positions. In the European Parliament elections of June 2004, thanks to a strong mobilisation of its supporters and an extremely low overall participation (21\%), the LPR reached $16 \%$ of the votes and acquired 10 seats in the EP. ${ }^{15}$ In the European hemicycle, the party has, as expected, joined marginal parliamentary groups. Most of the LPR MEPs joined the Independence/Democracy group. Some of them ended up unattached to any political group and 5 MEPs have been persuaded by the leader of PiS, Jarosław Kaczyński, to join the UEN.

This brief overview of the transnational affiliation process does not provide a complete assessment of the transnational factor. Its impact seems to have been the most important during the first period of the enlargement process, in the 1990s. At the time, the parties, who were involved in the dialogue with the European party federations (such as the Democratic Left Alliance - SLD, UW and AWS in the Polish case) had to prove their commitment to a common set of norms and values in their programmatic declarations and slightly clarify their organisational structures (Dakowska, 2002). The 'conformist pressures' suggested by Pridham (2008) could be observed especially in the case of the former communist parties. However, it bears mentioning that some CEE parties were actively pursued by different European party federations and in these cases the formal conditions of application could be loosened (Dakowska, 2002). All in all, the Polish party political landscape in the final phase of accession negotiations and until the aftermath of accession does not fully confirm Pridham's hypothesis about the softening of the EU related party positions as being a result of transnational pressures. On the contrary, parties like PiS, LPR and Self-Defence temporarily radicalised their discourse on European issues. It could be argued that this radicalisation concerned groupings and leaders who were - or felt - partly excluded from the transnational 
dialogue and socialization forums. But in order to fully explain this evolution, we have to turn to the domestic arena.

\section{The use of European issues in the structuring of the political field in Poland}

The relative weight of the European variable, which plays a minor role in the structuring of the party political system as a whole as well as in the priorities of most voters, should not be overestimated (see Batory, 2009; Haughton, 2009). But how can we explain the changing positioning of the political parties on European issues? How can we analyse the varying patterns of the benefits parties can draw from Europe? One of the biggest challenges in the study of party attitudes towards European integration is to explain change, which necessitates taking into account the time variable. On a long term, it is said that left-wing political parties, which were partly critical of European integration, have progressively converted to Europe, as social policies and environmental issues have been extended to the supranational level. But how can we understand and explain short-term, cyclical and contingent variations? In order to do that, we should take a closer look at the domestic political arenas.

\section{Party references to European integration: changing attribute or tool?}

The use of European integration may be considered in a dynamic way, as a strategic tool in party realignments (see Neumayer 2008). The patterns of reference to European issues and the degree to which party leaders chose to position themselves on the pro/anti European axis are related to the specificities of each national political field. The first problem with numerous available cross-country comparisons is that they usually lead to elaborating new typologies. On the one hand, these studies provide useful indications on the political party landscapes. On the other hand, they do not always escape the trap that consists in applying labels (such as populism, Euroscepticism, Europhobia, EU-optimism and its variations and so on) that are used by the politicians themselves or by journalists. These categories are neither precise nor heuristically pertinent. Although the limits of theses taxonomies have been largely stressed, a number of analysis still stick to these labels, as if there was no alternative in considering the partisan references to the European issues.

A liberal party such as the Polish PO is usually qualified as Euroenthusiast, albeit with nuances linked to its episodic criticism of the constitutional treaty (Markowski, 2006). Among 
parties qualified as populist in Poland, most analysts cite Self-Defence, but some add the LPR, some others the PSL to this list (Markowski, 2006). The PSL case illustrates the difficulties in authoritatively categorising a party position on EU issues: while it had been described as 'soft Eurosceptic' by Szczerbiak and 'Euroenthusiast' by Kopecký and Mudde (2002), Szczerbiak acknowledges that there is not enough evidence to determine "whether the Polish Peasant Party was optimistic of pessimistic about the EU's actual trajectory' (Szczerbiak, 2008: 239). The PiS is qualified as a conservative and Eurosceptic party (Kopecký, Mudde, 2002), with the caveat that since 2005 it 'has become' a Christian/national Populist party (Markowski, 2006). In his analysis Szczerbiak (2008) shows that a proper labelling of PiS is more complicated than it could seem. Thus the party's 'Eurosceptic turn' appears mainly as the result of a strategic positioning vis-à-vis the liberal PO and the more radical LPR. Eventually, the party's official position on European integration on the eve of the EU elections took the form of vague commitments to intergovernmentalism. But as the PiS called for a yes vote in the 2003 accession referendum, its opposition to the EU integration project is far from being certain and classifying the party as Eurosceptic 'was probably wrong' (Szczerbiak, 2008: 239).

This sudden transformation of the party political label leads me to the second criticism: most analyses have difficulties in explaining changes of party positioning. They describe and classify the party discourse at the $t$ or $t+1$ moment. The difference between these two stages appears like in a kaleidoscope: the colours, the shapes and the alignment of party configuration have changed. But we are not told how and especially why this configuration has changed. Thus, Markowski (2006) initially characterises the League of Polish Families and Self-Defence by their 'hard' Euroscepticism. Then we are told that 'after the positive result of the EU referendum, the leaders of both parties rapidly became soft Eurosceptics' (Markowski, 2006: 132). How does a 'hard Eurosceptic' suddenly become a 'soft Eurosceptic'? If one chooses the hypothesis that attitudes towards the EU are the expression of ideological, deeply rooted cleavages, such a quick change seems unlikely. If on the contrary we consider the party positioning on European issues as being the expression of strategic calculations, this shift seems more plausible. But in the latter case the position on European integration cannot be considered as an attribute that represents a core part of the party's identity.

Instead of that, I would suggest considering Euroscepticism and other 'markers' used in political struggles not as attributes but rather as tools used by politicians to distinguish themselves from other political organizations or party factions and legitimise their own 
positions. Laure Neumayer's works provide a fine comparison of the uses of this tool in three EU candidate/new member states, which encompass the whole political arena. Thus, reference to Europe is used to distinguish mainstream from protest parties, or political parties which compete for a similar electorate or positions, or different party factions among themselves (Naumayer, 2008). Consequently, it is questionable whether the notion of Euroscepticism, or 'soft Euroscepticism', is a useful heuristic tool to explain the dynamics of party realignments. The problem is that this kind of vague notion entails the risk of 'degreeism'. There are different kinds of Euroscepticism and variations of 'soft Euroscepticism'. Thus the occasional softening of the LPR's discourse or the occasional toughening of the PO's discourse leads to their labelling as 'soft Eurosceptics'. However, the juxtaposition of those two formations is not of much help to understand their political stances. In fact, these two parties have been strongly opposed on most issues, including the integration/sovereignty issue. The LPR clearly has played the card of a protest, marginal party while the PO has positioned itself as a mainstream, centre-right party.

These 'taxonomic approaches to Euroscepticism' are difficult to implement as they fail to take into account the patterns of party competition and consider parties as monolithic entities (Neumayer, 2008). Instead, the parties' positioning on EU issues should be systematically replaced in their domestic political context and considered relationally. It seems important to take into account the whole political configuration, within which each organisation seeks to get the upper hand while opposing the others (Bourdieu, 1981). This pleads for a revalorisation of country-specific case studies or small-n comparisons. At the same time the comparative approach is necessary, as it is difficult to deduce general rules from a single country analysis. What may be functioning in the Slovak case at some point like the disqualifying of anti-EU discourse at the executive level (Henderson, 2008) - may not be the case in other temporal or political contexts (see my analysis of the Polish case below). In the light of these difficulties, it seems interesting to focus on specific temporalities of European and national political events, such as elections (both on national and European levels), referenda, negotiations for accession, public campaigns or other public debates etc., which can be used as windows of opportunity by party leaders.

\section{The changing reference to European integration as an instrument of inter-party repositioning}


In Poland, but also in other EU candidate states, the reference to Europe was initially used in a consensual way, as a synonym of the break with the authoritarian past (Neumayer, 2006; Henderson, 2008). During the first decade of transformations, notwithstanding noticeable divergences, the proportion of politicians who overtly opposed to European integration was low. The opinion polls reflected a vast public support to the project of accession to the EU. With the beginning of accession negotiations, the decrease in public support to the accession project was noticeable in the polls. In the political arenas, parties increasingly opposed and argued about the modalities and prospects of the accession (Szczerbiak, 2008). This was linked to the fact that European issues were no longer considered as external political issues; they became integrated to internal political decisions and policies (Neumayer, 2003). At that time, the criticism of some aspects of European integration ceased to be a factor of ostracism and became evidence of a pragmatic attitude. The demonstrative invocation of 'national interests' was used in Poland to disqualify political opponents in the government. Its members were constantly accused of being servile in the accession negotiations.

One of the limits of the Euroscepticism framework is that it focuses on parties who are critical or opposed to European integration but fails to analyse the uses of Europe by mainstream political parties (Neumayer, 2008). On the eve of the accession the Civic Platform considered as a liberal party and classified among the Euroenthusiasts (Kopecký, Mudde, 2002), engaged in an escalating criticism of the European constitutionalization process. One of the PO leaders, Jan Rokita, a former member of the very pro-European UW, launched, in September 2003, the catchphrase 'Nice or death' to defend the provisions of the Nice treaty, considered as optimal for Poland. In the process, the PO put pressure on Leszek Miller's socialdemocratic government, forcing him to oppose the proposal of the double majority reform in the Council. This action set new standards in the Polish political debate, as the defence of the Nice Treaty and especially of its Council voting system became imperative for all the governments to come.

This periodic toughening of the position towards some specific aspects of the European institutional reforms can be explained by the structural electoral competition between the Civic Platform and the Law and Justice. Both parties fought for the image of a pragmatic party, defending the interests of Poland and capable of negotiating on their own terms with the EU. This being said, the overall support to European integration has remained a constitutive value of the Polish political system and a factor of legitimacy. It has produced a 'barrier effect' (Harmsen, 2005) in that the parties who aspire for governmental positions can 
hardly violate this broad consensus, as the final resolution of the conflict over the ratification of the constitutional treaty proves: the PiS did not end up crossing this thin line of support for further supranational integration.

On the eve of the accession to the EU, but also in its aftermath, political parties who used a 'Eurosceptic' or sovereignist discourse have tended to take advantage of the fears and uncertainties present in the social groups who feared that accession would weaken their already fragile social position. In a fierce competition with the Civic Platform, the Law and Justice leaders have chosen to position their organisation as an anti-establishment party. Interestingly, this strategy has been pursued even after the elections of 2005, which gave the control of the executive to the PiS. After the elections, the Prime Minister Jarosław Kaczyński has developed an anti-communist and anti-corruption discourse. Its strongly anti-elitist accents added to the image of what is considered to be a populist discourse. The PiS also tried to draw a new dividing line between the promoters of a 'liberal Poland' and a 'solidary Poland' while positioning itself as a defender of the 'national interest' of the weak social groups. Together with his twin brother, the President Lech Kaczyński has announced the beginning of a IVth Republic which would ensure the moralisation of political life and 'decommunization'. The PiS did not hesitate to use references identified with the radical right repertoire, such as the defence of national identity or suspicion against Germany. It announced a tough stance towards the European Union.

The coalition with the protest parties, the Self-Defence and the League of Polish Families, set up in 2006, has awakened numerous fears and criticisms. ${ }^{16}$ During the European Council debates on the modified treaty project in June 2007, the Polish representatives were opposed to any kind of compromise and thus isolated. Following the tried and true strategy of mobilising historical references in the public political discourse, Prime Minister Kaczyński has used the number of Polish victims during the World War II to justify his demand for more Polish votes in the EU Council. ${ }^{17}$ The suspicion and growing criticism of the government towards European decision-making can be considered as an 'incitation effect' (Harmsen, 2005), as these critical positions have paved the way for a radicalisation of Eurocritical positions in the domestic political field

The heated political debates in Poland in Spring 2008 over the ratification of the Lisbon treaty have stressed the salience of European issues in the inter-party power relations. The PiS expressed its opposition to the ratification of the Treaty which had been negotiated by its own leaders a few months before. In March 2008, President Kaczyński made a TV declaration illustrated by a map of interwar Germany and a film showing a homosexual wedding in 
Toronto. By declaring that 'everything in the EU is not necessarily good for Poland' he suggested that the Charter of Fundamental Rights would allow German citizens to claim in the European Court of Justice and ask for compensation for their goods left in Poland as a consequence of the treaty of Potsdam. The party leader Jarosław Kaczyński asked for the introduction of a preamble to the ratification law, which would guarantee the sovereignty of the Polish state and underline that in some issues the Polish constitution remained the relevant legislation. ${ }^{18}$ The change of position of the former Prime Minister appeared as paradoxical to some commentators, as he had, together with his presidential twin brother, negotiated the treaty and presented it at the time as a 'great victory' of his government.

To explain this evolution, we have to take into account the modified power relations between the Polish political parties. As the principal government party, the PiS had to moderate its position on EU issues to a certain extent, as it played the Community game in the Council and European Council. It entered the opposition upon losing the October 2007 elections to the Civic Platform. Until 2010, the PiS has however been represented in the executive by President Lech Kaczyński. ${ }^{19}$ Moreover, by gaining 32\% of the votes in the 2007 parliamentary elections, the PiS has managed to preserve its strong position, while integrating the voices of the extreme right and protest party voters (LPR and Self-Defence). Both of the latter barely reached $1 \%$ of the votes and did not enter the Parliament. This means that the PiS benefited from the votes of the citizens who had previously voted for LPR and Self-Defence in former elections. This also explains the radicalization of the PiS's political discourse, which has tried in this context to position itself further on the right. By demanding the introduction of a special preamble to the Lisbon Treaty ratification law, the leader of the PiS sent a message to the 'Eurosceptic' wing within his party, close to the ultra-catholic and nationalist Radio Maryja. One of the explanations of this tactic is that the PiS was fighting the risk of the emergence of a new party on its right, which would both be opposed to European integration and programmatically based on moral issues such as a total ban of abortion. ${ }^{20}$

The criticism of the Lisbon Treaty has however proved a risky political venture, notwithstanding the short-term political gain for PiS. The party's leaders were aware that risking the non-ratification of the Treaty would lead to the political marginalisation of the PiS in the national and European political space. A referendum on this issue, requested mainly by far right MPs, could lead to the discredit of the conservative right, as the majority of the Polish population was deemed pro-European. The Civic Platform understood this and announced, in March 2008, that if no compromise were found in the Parliament (where a qualified majority of $2 / 3$ was necessary for the ratification), it would organise a national 
referendum. Finally a compromise was found and the Treaty was ratified in the Parliament on April $1^{\text {st }}, 2008$. In his speech in front of the Parliament, the Prime Minister Donald Tusk presented the text championed at different times by representatives from all the mainstream parties: conservatives, liberals and the left. With the reference to the responsibility of different parties for the text, he sketched the limits of the political acceptability of criticism: all the main legitimate parties were expected to support the Treaty.

The conflict that has opposed the liberal Civic Platform and its leader Donald Tusk to the PiS, represented by the former Prime minister Jarosław Kaczyński, crystallises not only an ideological tension between politicians more or less in favour of deeper EU integration. It reflects the patterns of party competition for the image of a pragmatic party, able to tackle the demands of the citizens. But this conflict also reinforces the internal party divisions. ${ }^{21}$ The controversy enabled the marginalised opposition on the left to seize the opportunity of more frequent media appearances. Calling for a quick ratification of the Treaty, the Left and Democrats (LiD) coalition leaders, such as Wojciech Olejniczak, tended to present the position of President Kaczyński and of the PiS as marginal and illegitimate. It is doubtful whether the episodic radicalisation of the presidential discourse has yielded the expected results, as European issues have a limited salience for the voters. Eventually, the President minimized his opposition to the Lisbon treaty presenting it as a tactical play and reaffirming that the Polish membership in the EU has proved to be a success. ${ }^{22}$ Facing the stable public support for the PO and the wide satisfaction with EU membership expressed in the polls, the strategy of radicalising the critique of the EU has lost its attractiveness.

We could ask whether the Polish case calls into question the relatively sound hypothesis which posits that there are no parties in Europe that would mainly define themselves according to their support or opposition to European integration (Harmsen, 2005: 78). On the one hand, the position towards European integration is only one element of inter-party divisions among others (such as economic, social, moral issues or the question of the attitude towards the past). But on the other hand, European issues have been a crucial factor in the positioning of the LPR as an anti-integration party since the beginning. This organisation is the result of a merger between different small parties and movements, mostly nationalist or clerical. Some of them had to leave the Electoral Action Solidarity in 2000, due to their opposition to the prospect of the Polish accession to the EU. Consequently, the League of Polish Families positioned itself largely through its opposition to European integration. It is notable that the LPR used the electoral campaigns of the accession referendum in 2003 and of the European elections to mobilise its electorate and gain visibility in the public space. During 
the first European elections in Poland in June 2004, the League of Polish Families benefited from a strong mobilisation of its electorate and a generalised abstention. ${ }^{23}$ As a result, it received almost $16 \%$ of the votes. The anti-integration mobilisation has remained the main repertoire of action of the LPR after its leaders left the government. The party was mobilised in favour of a referendum on the Lisbon Treaty and against the European constitution. ${ }^{24}$ The opposition to the introduction of the Euro in Poland played on fears of loss of sovereignty and inflation. ${ }^{25}$ Following the 2007 parliamentary defeat, these anti-integrationist appeals mainly came from the Eurosceptic MEPs in the European parliament, which remained an important political tribune for the LPR until its defeat in the 2009 European elections. ${ }^{26}$ This analysis shows that the mobilisation of European issues can be a burning issue in the inter-party competition.

\section{Conclusion}

Even if European integration has had a limited impact on party configurations as a whole, it was a significant element in the party competition. References to the accession negotiations, to conditions imposed during the process or to institutional reforms were frequently made in the repositioning of political parties on the domestic arena. In the process of the Europeanisation of party competition, the transnational links set up with the European party federations were a first way of redefining a party's position according to the European political offer. A closer look on a single country's case shows the important fluidity and dynamic of the process. The quantitative studies of party Euroscepticism provide maps of the average positioning of different parties and inform us about the general tendencies. But they fail to grasp the dynamics of the reference to the EU and the fundamentally relational character of inter-party competition which explains the change in the positioning of some parties.

Qualitative case studies - if they could be systematised - could fill this gap and answer some unresolved questions. Out of several dimensions detailed by Tim Haughton (2009) to evaluate the impact of the EU accession on the CEE political parties, indicators such as the 'prominence of European issues in party programmes or the 'role of European Policy Specialists within party decision making' does not seem very heuristic (Szczerbiak, Bil, 2009). However, use of the European issue in the inter-party competition opens more encouraging avenues of research. It is worth being applied in countries, in which European integration issues have occupied a wide space in the public debates, such as Poland (Horolets, 2006). 
These issues seem to have been an episodically important element of differentiation for the most and the least pro-European parties. Therefore, I suggest that it may be useful to shed light on particular stages (pre-negotiations, negotiations, the moment of the accession, after the accession), on the national political temporalities (elections, building of coalitions) and also on particular debates - which may differ in each country. These moments allow the observation of the way inter-party power relations and competitions for voters crystallise, and the explanation of shifts in the positioning of different parties.

Table 1

Schematic presentation of main Polish political parties represented in the Parliament during the parliamentary terms since 1989*

(the bold characters indicate the parties, which participated in the government during the indicated period or part of it)

\begin{tabular}{|c|c|c|c|c|c|c|c|}
\hline & Left** & $\begin{array}{c}\text { Centrist, } \\
\text { liberal }\end{array}$ & $\begin{array}{c}\text { Centre- } \\
\text { right, } \\
\text { liberal*** }\end{array}$ & $\begin{array}{c}\text { Agrarian } \\
\text { (moderate) }\end{array}$ & $\begin{array}{l}\text { Agrarian } \\
\text { (radical) }\end{array}$ & $\begin{array}{c}\text { Conservative, } \\
\text { Right***** }\end{array}$ & $\begin{array}{l}\text { Far } \\
\text { Right }\end{array}$ \\
\hline $\begin{array}{l}1989- \\
1991\end{array}$ & SdRP & UD & KLD & $\overline{P S L}$ & & KPN & \\
\hline $\begin{array}{l}1991- \\
1993\end{array}$ & $\begin{array}{c}\text { SdRP } \\
(=>\text { SLD }), \\
\text { UP }\end{array}$ & UD & KLD & PSL & & $\mathrm{PC}, \mathrm{KPN}$ & \\
\hline $\begin{array}{l}1993- \\
1997\end{array}$ & SLD, UP & $\begin{array}{c}\text { UD }=> \\
\text { UW } \\
(1994)\end{array}$ & & PSL & & KPN & \\
\hline $\begin{array}{l}1997- \\
2001\end{array}$ & SLD & UW & & PSL & & AWS, ROP & \\
\hline $\begin{array}{l}2001- \\
2005\end{array}$ & SLD, UP & & $\mathrm{PO}$ & PSL & Samoobrona & PIS & LPR \\
\hline $\begin{array}{l}2005- \\
2007\end{array}$ & SLD & & $\mathrm{PO}$ & PSL & Samoobrona & $\mathbf{P i S}$ & LPR \\
\hline $\begin{array}{l}2007- \\
2010\end{array}$ & SLD & & PO & PSL & & PiS & \\
\hline
\end{tabular}

* The purpose of this table is to provide a simplified map of the Polish political parties' positioning. It does not aim to propose any new classification, as the stances of the mentioned parties vary, as analysed in this article. ** SdRP: Social Democracy of the Republic of Poland, created in 1990 as a successor of the Polish United Workers Party. It was the leading member of the Democratic Left Alliance (SLD) coalition, created in 1991. SLD became a political party on its own in 1999. UP: Labour Union: social-democratic party issued from the left wing of the Solidarność movement, founded in June 1992.

*** KLD: Liberal-Democratic Congress. KLD merged with the Democratic Union (UD) in April 1994. PO was composed of liberal wings of the AWS coalition and of conservative members of the Union of Freedom (UW) after the split of these parties.

**** PC: Centre Agreement, Christian-democratic party founded by Jarosław Kaczyński. PC joined the AWS coalition in 1997 until 2001 when the Kaczyński brothers launched the Law and Justice (PiS) party. KPN:

Confederation of Independent Poland, founded in 1979 (nationalist right). ROP: Movement for the 
Reconstruction of Poland. The AWS coalition gathered several political groups, from the centre-right to the nationalist and clerical right. Thus, it is particularly difficult to classify it.

\section{$\underline{\text { References }}$}

Baisnée Olivier, Pasquier Romain (eds) (2007), L'Europe telle qu'elle se fait. Européanisation et société politiques nationales, Paris, CNRS Editions.

Batory, Agnes (2002), 'Attitudes to Europe: ideology, strategy and the issue of European Union membership in Hungarian party politics', Party Politics, 8 (5), p. 525-539.

Batory, Agnes (2009), 'The Dog that Did Not Bark? Assessing the Impact of the EU on Party Politics in Hungary', Journal of Communist Studies and Transition Politics, 25 (4), $427-$ 446.

Batory, Agnes, Sitter Nick (2004), 'Cleavages, competition and coalition-building: Agrarian parties and the European question in Western and East Central Europe', European Journal of Political Research, 43 (4), p. 523-546.

Bourdieu Pierre (1981), 'La représentation politique. Eléments pour une théorie du champ politique', Actes de la recherche en sciences sociales, $\mathrm{n}^{\circ}$ 36-37, p. 3-24.

Czernicka Katarzyna (2004), 'La Ligue des familles polonaises. Montée en puissance d'un parti anti-européen', Le courrier des pays de l'Est, n 1045, September-October, p. 85-94.

Dakowska, Dorota (2002), 'Beyond Conditionality: EU Enlargement, European Party Federations and the Transnational Activity of German Political Foundations', Perspectives on European Politics and Society 3 (2): 271-96.

Dakowska Dorota (2005), 'German Political Foundations: Transnational Party go-betweens in the Process of EU Enlargement', in: Wolfram Kaiser/Peter Starie, (eds.), Transnational European Union, London, Routledge, p. 150-169.

De Waele Jean-Michel (2003), 'Le paysage partisan polonais entre spécificité et convergence', in: J.-M. De Waele (ed.), La Pologne et l'intégration européenne, Brussels, Editions de l'Université de Bruxelles.

Devin Guillaume (1998), 'L'internationale socialiste en Europe centre-orientale : définition et rôle des 'amis politiques', in: Pascal Delwit, Jean-Michel De Waele (eds), La gauche face aux mutations en Europe, Bruxelles, Editions de l'Université de Bruxelles.

Evans Geoffrey (1998), 'Euroscepticism and Conservative Electoral Support: How an Asset Became a Liability', British Journal of Political Science, 28 (4), p. 573-590.

Featherstone K., Radaelli Claudio M., (2003), The Politics of Europeanization, Oxford, Oxford University Press. 
Fuchs Dieter, Magni-Berton Raul, Roger Antoine (eds), (2009), Euroscepticism. Images of Europe among mass publics and political elites, Opladen \& Farmington Hills, MI, Barbara Budrich Publishers.

Fuchs Dieter, Roger Antoine, Magni-Berton Raul, (2009 b), 'European Cleavage, Euroscepticism and Support of the EU: A Conceptual Discussion', in: Ibid (eds), Euroscepticism. Images of Europe among mass publics and political elites, Opladen \& Farmington Hills, MI, Barbara Budrich Publishers.

Goetz Klaus H., Hix Simon (2000), 'Introduction: European Integration and National Policy Systems', West European Politics, 23 (4), issue 'Europeanised Politics? European Integration and National Political Systems', p. 1-26.

Green Cowles Maria, Caporaso James, Risse Thomas (dir.) (2001), Transforming Europe: Europeanization and Domestic Change, Ithaca, NY, Cornell University Press.

Harmsen Robert, Spiering Menno (eds) (2004), Euroscepticism: Party Politics, National Identity and European integration, Amsterdam, Rodopi.

Harmsen Robert (2005), 'L'Europe et les partis politiques nationaux : les leçons d'un nonclivage', Revue Internationale de Politique Comparée, 12 (1), p. 77-94.

Harmsen Robert (2008), 'The Evolution of Dutch European Discourse: Defining the 'Limits of Europe', Perspectives on European Politics and Society, 8 (3), p. 316-341.

Haughton Tim (2009) 'Driver, Conductor or Fellow Passenger? EU Membership and Party Politics in Central and Eastern Europe', Journal of Communist Studies and Transition Politics, 25 (4), p. 413-426.

Haughton Tim, Rybár Marek (2009), 'A Tool in the Toolbox: Assessing the Impact of EU Membership on Party Politics in Slovakia', Journal of Communist Studies and Transition Politics, 25 (4), 540-563.

Hellström Johan (2008), 'Partisan responses to Europe: the role of ideology for national political parties' positions on European integration', Journal of European Public Policy, 15 (2), March, p. 189-207.

Henderson Karen (2008), 'Exceptionalism or convergence? Euroscepticism and Party Systems in Central and Eastern Europe', in: Szczerbiak Aleks, Taggart Paul, (eds), (2008), Opposing Europe? The Comparative Party Politics of Euroscepticism, vol. 2, Comparative and Theoretical Perspectives, Oxford, Oxford University Press.

Héritier Adrienne \& al. (2001), Differential Europe. The European Union Impact on National Policymaking, Oxford, Rowman \& Littlefield. 
Hooghe Liesbet, Marks Gary (2007), 'Sources of Euroscepticism'Acta Politica, 42 (2), p. 119-127.

Horolets Anna (2006), Obrazy Europy w Polskim dyskursie publicznym (Images of Europe in the Polish Public Discourse), Cracow, Universitas.

Jacquot Sophie, Woll Cornelia (dir.) (2004), Les usages de l'Europe. Acteurs et transformations européennes, Paris, L'Harmattan.

Kopecký Petr, Mudde Cas (2002), 'The Two Sides of Euroscepticism: Party Positions on European Integration in East Central Europe', European Union Politics, 3 (3), p. 297-326.

Ladrech Robert (2002), 'Europeanization and political parties: Towards a Framework for Analysis', Party Politics, 'The Europeanization of Party Politics', 8 (4), p. 389-403.

Lewis Paul, Mansfeldová Zdenka (eds.) (2006), The European Union and Party Politics in Central and Eastern Europe, Palgrave, Basingstoke.

Mair Peter (2000), 'Limited Impact of Europe on National Party Systems', West European Politics, 23 (4), p. 27-51.

March James G., Olsen Johan P., (1998) 'The Institutional Dynamics of International Political Order', International Organization, 52 (4), p. 943-969.

Markowski Radosław (2006), 'EU Membership and the Polish Party System', in: Paul Lewis, Zdenka Mansfeldova (eds.), The European Union and Party Politics in Central and Eastern Europe, Palgrave, Basingstoke.

Marks Gary, Wilson Carole J., Ray Leonard (2002) 'National Political Parties and European Integration', American Journal of Political Science, 46 (3), p. 585-594.

Marks Gary, Hooghe Liesbet, Nelson Moira, Edwards Erica (2006), 'Party Competition and European Integration in the East and West. Different Structure, Same Causality', Comparative Political Studies, 39 (2), p. 155-175.

Marks Gary, Hooghe Liesbet, Steenbergen Marco R., Bakker Ryan (2007), 'Crossvalidating data on party positioning on European integration', Electoral Studies, 26 (1), p. 23-38.

Neumayer Laure (2003), 'L'impact de la future adhésion à l'Union européenne sur les structures politiques des pays d'Europe centrale : l'usage des thématiques européennes dans les compétitions politiques', in: Antoine Roger (dir.), Des partis pour quoi faire? La représentation politique en Europe centrale et orientale, Bruxelles, Bruylant.

Neumayer Laure (2006), 'L'enjeu européen dans les compétitions partisanes en Europe centrale', Revue française de science politique, 56 (5), October 2006, p. 789-812. 
Neumayer Laure (2008), 'Euroscepticism as a political label: the use of European Union issues in political competition in the New Member States', European Journal of Political Research, 47 (2), p. 135-160.

Pridham Geoffrey (2008), 'European Party Cooperation and Post-Communist Politics: Euroscepticism in Transnational Perspective', in: Szczerbiak Aleks, Taggart Paul, (eds), Opposing Europe? The Comparative Party Politics of Euroscepticism, vol. 2, Comparative and Theoretical Perspectives, Oxford, Oxford University Press, 2008.

Radaelli Claudio M. (2001), 'The domestic impact of European Union public policy: notes on concepts, methods, and the challenge of empirical research', Politique européenne, $\mathrm{n}^{\circ} 5$, Autumn, p.107-142.

Roger Antoine (2001), 'Perspectives d'intégration à l'Union européenne et formation des systèmes de partis dans les pays d'Europe centrale', Politique européenne, n³, p. 86-113.

Schimmelfennig Frank, Sedelmeier Ulrich (eds) (2005), The Europeanization of Central Europe, Ithaca, Cornell University Press.

Szczerbiak Aleks, Taggart Paul, (eds), (2008), Opposing Europe? The Comparative Party Politics of Euroscepticism, vol. 1, Case Studies and Country Surveys, Oxford, Oxford University Press, 2008.

Szczerbiak Aleks, Taggart Paul, (eds), (2008), Opposing Europe? The Comparative Party Politics of Euroscepticism, vol. 2, Comparative and Theoretical Perspectives, Oxford, Oxford University Press, 2008.

Szczerbiak Aleks, Bil Monika (2009), 'When in Doubt, (Re-)Turn to Domestic Politics? The (Non-)Impact of the EU on Party Politics in Poland', Journal of Communist Studies and Transition Politics, 25 (4), 447-467.

Szczerbiak Aleks (2008), 'Opposing Europe or Problematizing Europe? Euroscepticism and 'Eurorealism' in the Polish Party System', in: Szczerbiak Aleks, Taggart Paul, (eds), (2008), Opposing Europe? The Comparative Party Politics of Euroscepticism, vol. 1, Case Studies and Country Surveys, Oxford, Oxford University Press, 2008.

Taggart Paul (1998), 'A Touchstone of Dissent: Euroscepticism in Contemporary Western European Party Systems', European Journal of Political Research, 33 (3), p. 363-388.

Taggart Paul, Szczerbiak Aleks, (2002), 'The Party Politics of Euroscepticism in EU Member and Candidate States', SEI Working Paper $n^{\circ} 51$.

Taggart Paul, Szczerbiak Aleks (2003), 'Theorising Party-Based Euroscepticism: Problems of definition, Measurement and Causality', SEI Working Paper $\mathrm{n}^{\circ} 69$. 
Taggart Paul, Szczerbiak Aleks, (2004), 'Contemporary Euroscepticism in the Party System of the EU Candidate States of Central and Eastern Europe', European Journal of Political Research, 43 (1), p. 1-27.

Whitefield Stephen, Rohrschneider Robert (2009), 'The Europeanization of Political Parties in Central and Eastern Europe? The Impact of EU Entry on Issue Stances, Salience and Programmatic Coherence', Journal of Communist Studies and Transition Politics, 25 (4), 564-584.

\section{Notes}

${ }^{1}$ I would like to thank Tim Haughton, Kevin Deegan-Krause and all the participants of the workshop 'Is Populism a Side-Effect of the Europeanization of Political Competition?' held during the ECPR Joint Sessions of Workshops, Rennes 2008 for their useful comments on a previous version of this text. Many thanks also to JeanYves Bart for his linguistic help. I am responsible for any remaining inaccuracies.

${ }^{2}$ Since the 1990s, the academic debate has triggered a large number of definitions of "Europeanization". The one proposed by Claudio Radaelli (2001) is clear and complete as it refers to: "Processes of (a) construction (b) diffusion and (c) institutionalization of formal and informal rules, procedures, policy paradigms, styles, 'ways of doing things' and shared beliefs and norms which are first defined and consolidated in the making of EU public policy and politics and then incorporated in the logic of domestic discourse, identities, political structures and public policies" (Radaelli, 200, p. 110). However, as will be shown later, we can also consider Europeanization not only as a and phenomenon, of which we can measure the extent and intensity, but also as a process, which has to be analysed through its social uses, i. e. the way social actors refer to the EU institutions, norms and regulations in order to position themselves within specific configurations (see Baisnée, Pasquier. 2007).

${ }^{3}$ Stemming from the journalistic discourse, which applied it to the attitude of the British Conservative Party towards the European integration in the 1980s, the term 'Euroscepticism' has triggered a flourishing academic literature. Paul Taggart proposed a pioneer definition of an 'idea of contingent or qualified opposition, as well as incorporating outright and unqualified opposition to the process of European integration' (Taggart 1998, p. 365). For a discussion of different attempts to define the logics of contestation of the European integration and to make it operational, see Fuchs, Roger, Magni-Berton (2009 b) or Neumayer (2008).

4 These opposite poles have been called 'gal' (green/alternative/libertarian) vs. 'tal' (traditionalism/authority/nationalism) (Marks, Hooghe \& al. 2006).

${ }^{5}$ The National Democracy (ND) was a nationalist right wing political movement founded in the end of the $19^{\text {th }}$ century Its main ideologue was Roman Dmowski. During the interwar years ND was the principal opposition to the ruling Polish Socialist Party (PPS). It claimed nationalist and anti-Semitic ideas.

${ }^{6}$ Interview with a representative of the EPP group, 21 February 2003.

${ }^{7}$ The decision to join a transnational party federation was often the result of strong controversies inside central European party presidencies.

${ }^{8}$ After the 2009 European elections, during which the PiS received 27,4\% of votes (with a weak participation of 24,53\%), 15 PiS MEPs joined the European Conservatives and Reformists group composed mainly by parties from the former Union for Europe of Nations and the European Democrats section of the EPP-ED.

${ }^{9}$ Interview with a PiS representative, October 2007.

${ }^{10}$ Marcin Libicki, Szymon Szynkowski, 'Polskie głosy i głosiki w Parlamencie Europejskim', Gazeta wyborcza, 23 September 2008.

${ }^{11}$ The decision of some PSL MEPs to cross over to the UEN entailed a split in the party at the domestic level. The defecting MEPs have been excluded from the PSL and founded the 'Piast' grouping. During the 2009 European elections the PSL won 7\% of the votes and 3 mandates in the EP. These 3 MEPs joined the group of the European People's Party (Christian Democrats), while other former PSL members were candidates on the PiS list. Some others were - unsuccessful - candidates under the Libertas banner.

${ }^{12}$ Interview with a LPR MEP, European Parliament, March 2008.

${ }^{13}$ Out of $58,85 \%$ of the voters who participated in the referendum $77,45 \%$ voted in favour of accession. 
${ }^{14}$ Interview with a LPR MEP in the European Parliament, March 2008. The mentioned interview with Giertych was published on June $12^{\text {th }} 2003$ by Gazeta wyborcza.

${ }^{15}$ In the 2009 elections, the LPR did not send any MEPs to Brussels, as it only got $1,1 \%$ of votes under the banner of Libertas.

${ }^{16}$ Paweł Śpiewak, 'Zwijanie demokracji', Dziennik, supplement Europa, 2 September 2006.

17 Konrad Niklewicz, Dominika Pszczółkowska, Jacek Pawlicki, 'Szczyt w Brukseli: pierwiastek na stół', Gazeta wyborcza, 22 June 2007.

${ }^{18}$ This demand sounds like a legal aberration: when it acceded to the EU, Poland accepted the principle of the primacy of Community law.

${ }^{19}$ The Presidential function in Poland is more than just a ceremonial position. The President represents the State in foreign affairs, leads the Armed Forces and has the right to veto legislative bills by refusing to sign them. The air crash on April 10 2010 , in which the President Kaczyński and his wife, 15 MPs and several senior government officials died, led to anticipated presidential elections in June 2010. It is difficult yet to tell how this tragedy will weigh on the Polish political competition.

${ }^{20}$ Politicians also carefully follow the opinion polls published daily in the press. Some of these polls considered that half of the PiS electorate is critical towards European integration. But some others showed that Radio Maryja's listeners did not necessarily vote as expected.

${ }^{21}$ Finally $68 \mathrm{MPs}$, all from the PiS, who voted against the Treaty, faced a dilemma: either they stayed in the party and had to accept the overall pro-integration position or they left the party to appeal to the traditionalist electorate in a different manner.

${ }^{22}$ Interview with President Kaczyński 'Prezydent: Przede wszystkim jestem Europejczykiem', Gazeta wyborcza, 10th January 2009.

${ }^{23}$ The participation did not exceed $21 \%$.

${ }^{24}$ On its website, this was visualised by a balance with a European flag and a Polish flag. 'Choose what is important for you' says the slogan. http://www.lpr.pl/

25 However, after the defeat in the 2007 elections, a positive campaign was launched (Yes to the zloty, http://www.zlotytak.pl/) to correct the image of an aggressive and negative party. Interview with a leader of the LPR in the European Parliament.

${ }^{26}$ The demand for the organisation of a referendum on the Lisbon Treaty was made by two MEPs elected on the LPR list, close to the clerical Radio Maryja: Witold Tomczak and Urszula Krupa. 